\title{
Art and Environmental Action, One Bird at a Time
}

\author{
Cameron Cartiere \\ Emily Carr University of Art + Design, Vancouver, BC, Canada \\ ccartiere@ecuad.ca
}

\begin{abstract}
The environmental problems of climate change and species decline can feel overwhelming. Individuals are often at a loss, questioning what impact they can actually have. Through chART Projects, we have witnessed the dramatic effect of communityengaged art as a direct path to environmental action and impact on local ecosystems. During the 27th International Ornithological Congress, bird enthusiasts from around the world focused their attention on Vancouver, Canada. This article is a reflection on how chART took advantage of this assembly, creating an ambitious venture aiming for a sustainable effect on the public's relationship to urban birds. As the Crow Flies was a public art project bringing creative connections to urban birds directly into the hands of the public. Works included sited-sculpture, community-engaged interventions, projections, workshops, performances, and 6,000 ceramic crows.

chART's founder, Cameron Cartiere has been working with an interdisciplinary team to address the loss of pollinators through Border Free Bees. That research project used environment-based art to engaged communities to take positive action to improve conditions for pollinators, with tremendous success. As the Crow Flies took a similar approach to highlight the loss of bird species and actions individuals could take to improve the odds for their feathered neighbours.
\end{abstract}

Keywords: public art, social practice art, environmental art, community engagement

To cite this article:

Cartiere, C. (2020) Art and Environmental Action, One Bird at a Time, The Journal of Public Space, 5(4), 7-24, DOI 10.3289I/jps.v5i4.13II

This article has been double blind peer reviewed and accepted for publication in The Journal of Public Space. (c) (P) This work is licensed under a Creative Commons Attribution - Non Commercial 4.0 International License https://creativecommons.org/licenses/by-nc/4.0/ 


\section{Introduction}

North America has more than 1.5 billion fewer birds than it did 40 years ago. Human activity kills millions of birds a year. Collisions with power lines, buildings and vehicles account for about 900 million bird deaths annually in Canada and the United States of America, while domesticated and feral cats kill another 2.6 billion - or about a quarter of the land-bird population. Loss of habitat to urban sprawl, farming and forestry is arguably an even bigger driver of long-term decline in bird populations. Scientists have noted that because of migration south, loss of habitat is an international problem - the cultivation techniques of coffee planters in South America can affect songbird flocks in Canada.

These startling facts and figures come from the comprehensive Partners-In-Flight study (Rosenberg et al, 2016) and concludes that urbanization, growth in agriculture and possibly even climate change have driven the decline in North American land-bird populations. The total number of continental land-birds stands at about 10 billion, down from about II.5 billion in 1970. The study's authors (academic, activist and government bodies in Canada and the United States of America) list 86 of North America's roughly 450 breeding species as vulnerable, with some populations expected to be halved in a matter of decades. Soon our forests may be silent.

But birds do much more than keep our green spaces musical. Healthy bird populations provide valuable ecosystem services such as pollination and insect control. Birds are also a bellwether of broader ecological health. A generation ago, it was sickly birds who proved to be the early warning signs of the environmental damage caused by the pesticide DDT. This crisis was brought to public attention through the work of nature writer and former U.S. Fish and Wildlife marine biologist, Rachel Carson'. So, in many ways, the status of our bird populations can indicate the status of our own health. These dramatic losses signal the need to expand our thinking and take more individual action when it comes to ensuring the well-being of birds and our environment. Provincial and federal initiatives across Canada have begun to take action to protect the Canadian Boreal Forest. ${ }^{2}$ But government intervention and the work of conservationists is only part of the solution. New ideas, new models, and new partners are required to educate and engage the public on the importance and the wonder of the birds who share our cites and contribute to our environmental health.

It is usually at this point in discussions about environmental action (at the end of a long list of facts and figures and mounting bad news), that I start to see the signs of panic or dismay in the eyes of my potential collaborators. As an artist working in the public realm, much of my practice engages with environmental issues and I tend to work with numerous collaborators to realize large scale projects. However, the scope and scale of the environmental issues that we face can seem overwhelming to so many individuals. The National Audubon Society's Survival By Degrees: 389 Bird Species on the Brink study (Wilsey et al, 2019) indicates that- that two-thirds (64\%) of North American bird species are at risk of extinction from climate change, but the study also concludes that if humans take action now we can help improve the chances for $76 \%$ of species at risk.

\footnotetext{
' Rachel Carson's 1962 book, Silent Spring, not only exposed the hazards of the pesticide DDT, but is often attributed as one of the leading texts that promoted public awareness of the vulnerability of nature to human technologies and interventions.

${ }^{2}$ In the 2018 federal budget, the Trudeau government committed $\$ 1.3$ billion towards the creation of protected areas in Canada.
} 
But what actions? And how? For how long? At what cost (economic, social, political)? At what sacrifice? The list questions grow and so many people never make the first move because they are overwhelmed by what appears to be an insurmountable amount of problems and challenges. But it has been my experience, as someone working in public arts since Suzanne Lacy first coined the phrase, 'new-genre public art' (1995) , that art can move both individuals and communities into action. This kind of 'artivism' (Goris and Hollander, 2017) is where art serves as a catalyst for action and change. It is also a communicative approach that recognizes the power of art to transcend cultural, social, economic and linguistic barriers. The key is to find the starting place. The point of entry for an individual to visualize their own involvement - to see where their specific actions actually contribute to the larger collective effort.

I have used this method of working in my teaching as well as with my work in public art. When I teach courses in environmental ethics or collaborating with nature, I always begin by acknowledging the enormity of the problem. No one individual is going to solve all the varying issues that are creating the global climate crisis. But if we all start from a point of passion (What is the key issue that really motivates you?), we can be more effective. A class of thirty students will likely have twenty-five different environmental topics they would like to address. Team up those students with overlapping interests and the class moves forward with twenty different lenses to look at the challenges facing the environment and potentially twenty different art and design initiatives to contribute to the collective solutions. Working with the larger public, the challenge is sometimes getting people to 'see' the problem. It is not always enough to illustrate the issues - a drawing doesn't necessarily move people into action. But to become involved in the actual making of the artwork, to 'see' through an immersive and physical experience - that requires people, even if only briefly, to become actively engaged.

\section{A Bird in the Hand}

As the Crow Flies was a community-engaged public art project, comprised of several artworks, that literally brought creative connections to urban birds directly into the hands of the hundreds of individuals living in and visiting Vancouver, British Columbia. The project began in 2018 and developed over seven months, culminating during the week of the $27^{\text {th }}$ International Ornithological Congress (August 19-26). This huge convention occurs every four years and this iteration was only the second time that the congress was convening in Canada, and the first time in Vancouver. So, this was a unique opportunity to not only engage with local audiences, but also bird enthusiasts from around the world who were focusing their attention on British Columbia. The City of Vancouver even shifted its annual Bird Week (a host of bird related activities and events normally scheduled in May) to coincide with the congress.

In addition to focusing attention on the environmental issues impacting bird populations, one of the aims of As the Crow Flies was to connect a broad range of public spaces

\footnotetext{
${ }^{3}$ My first significant encounter with public art was working with Suzanne Lacy at the California College of Arts \& Crafts in Oakland, California. The 1994 event was a three-day symposium bringing together artists, curators, and writers from across the USA to discuss the expanding field of public art beyond sited sculptures and towards more socially-engaged art practices. The event, Mapping the Terrain, was the foundation for the same titled anthology.
} 
across Vancouver. Looking at a city map, connecting the multiple artworks in a straight line (borrowing from the old moniker "as the crow flies") created a virtual ten kilometre path that bisected the city and provided the public a unique perspective of important neighbourhoods and green spaces along the way: including Strathcona, Mount Pleasant, Queen Elizabeth Park, VanDusen Botanical Gardens, and the southernmost point of the new Arbutus Greenway.

For the last several years, prior to developing As the Crow Flies, I had been working with a team of artists, designers, scientists, conservationists, municipal partners, school groups, and volunteers to address the loss of pollinators across Canada through a SSHRC-funded ${ }^{4}$ collaboration called Border Free Bees (BFB). This award-winning research project used environmental-based art as one of the primary means for engaging a broad community to take positive action to improve conditions for native bees and other pollinators with tremendous success (Cartiere and Holmes, 2019). With the public art project, As the Crow Flies, I wanted to utilize some of the same creative methodologies to highlight not only the concerning loss of bird species, but also real actions individuals could take to improve the odds for their feathered neighbours.

For many in the city, the crow is the unofficial mascot of Vancouver. Every evening, the skies fill with the easily recognizable silhouettes of thousands of crows marking the daily migration across Metro Vancouver to the Still Creek Rookery in Burnaby. This rookery is one of the largest in North American, whose crow population fluctuates between 6,000 and 20,000 depending on the time of year. Scores of people come to view the nightly return of these birds to this peculiar strip of trees wedged between the Costco and the McDonald's parking lots. Other people have mixed feelings about crows, from ominous tales of being harbingers of misfortune to the more practical concerned about being "dive-bombed" while walking down the sidewalk. Highly intelligent, social, resourceful and playful, crows are a fascinating species (Haupt, 2009; Marzluff and Angell, 2013; Savage 20I5). Sometimes confused with the more mythologized raven, the crow is a ubiquitous bird across Canada and around the world. It is this commonality of presence in our shared landscape, the mixed feelings they evoke, and the overt attraction they stir within us, that makes the crow the perfect "gate-way bird" to open up a conversation about the shocking decline of birds in our environment. For this project, we turned to our native member of the bird family Corvidae. The Northwestern Crow (Corvus caurinus) is slightly smaller than its cousin the American Crow (Corvus brachyrhynchos) and some scientists think that the because of cross breeding, the Northwestern Crow is being genetically edged out of existence (Marzluff and Angell, 2007).

While developing the Border Free Bees project, we used the Western Bumble Bee (Bombus occidentalis) as our ambassador into the world of pollinators. Like the crow, bumble bees are easy to spot in the field and often have familiar associations. But the Western Bumble Bee, like the Northwestern Crow, is native to our region and while once very common, both bee and crow are becoming rare. To increase pollinator awareness and provide concrete environmental solutions, our collaborative team

\footnotetext{
${ }^{4}$ Border Free Bees was funded by a Partnership Development grant from the Social Sciences and Humanities Research Council (SSHRC) in collaboration with Emily Carr University of Art + Design, University of British Columbia Okanagan (UBCO), the City of Richmond, BC, the City of Kelowna, and numerous industry partners. The principle investigator was $\mathrm{Dr}$. Cameron Cartiere and the co-investigator was Associate Professor Nancy Holmes (UBCO). For more information see www.borderfreebees.com
} 
created a series of exhibitions, public projects, earthworks, and community art events to engage people into the world of pollinators. The Western Bumble Bee introduced our audiences to the $800+$ native bees that live in Canada, over 450 of whom are in British Columbia. Translate our methodology of community engagement to the world of birds, the Northwestern Crow became the ambassador for the 459 species in 46 different bird families in BC. With Border Free Bees, we created public art pollinator pastures and gallery installations with 10,000 laser-cut bumble bees from hand-made seed paper (each bee being a mini pasture waiting to be planted). For As the Crow Flies, we were inspired in part by British artist Clare Twomey's installation Trophy (2006) in London's V\&A Museum. ${ }^{5}$ Twomey created 4,000 blue clay birds. Perched all over the ground and around some of the museum's most famous historic sculptures, these tiny blue birds were just asking to be taken home. Within five hours of opening, the public had "stolen" every single one of these birds. While this was the intent of the installation, no one formally invited visitors to take the birds home, people just followed the behaviour of others in the space. The installation was intriguing and certainly the sheer number of birds had a dramatic impact, but I wondered if such an approach could actually address our larger issue of bird decline and if the art objects, now in the hands of so many members of the public could serve less as decorative items and more as direct symbols of action.

Being well versed in the power of multiples (from 2015 to 2018 we have created over 18,000 bees for the BFB traveling exhibition For All is For Yourself) and involving community directly in the making of environmental artworks that dramatically increased the immediate actions individuals are willing to take to promote positive environmental change; my collaborative team (chART Projects ${ }^{6}$ ) developed three public art works within the As the Crow Flies project.

Our first community-engaged work was Fledglings (figure I) $-6,000$ baby ceramic Northwestern crows made in community workshops using clay, press molds, and simple ceramic hand tools. These figures, designed by myself and artist, Jess Portfleet were made over the course of six months in workshops held at community centres, public squares, and the public spaces at Emily Carr University of Art + Design.

When we observe crows, it is usually the adult birds we see. One seldom sees chicks or fledglings in the nest, particularly in our city parks and street trees as urban crows make their nest much higher in the canopy then rural crows. The 'dive-bombing' activity crows display is often in protection of their nests (Marzluff and Angell, 2013; Savage 2015). The emphasis of this artwork was on the unseen inhabitants of the nest; to provoke an awareness of the vulnerability of the small creatures and to create a mindfulness of the host of other bird species trying to raise their young in our shared city. Our choice to use ceramics was intentional as the resulting birds would possess a degree of fragility reflective of the fragility of fledglings in our urban spaces.

\footnotetext{
${ }^{5}$ http://www.vam.ac.uk/content/articles/c/clare-twomey/

6 chART Projects is not really a "who" but more of a "what" - a collective method of working cooperatively towards shared aspirations and objectives. Launched by Dr. Cameron Cartiere in 20I0, the current focus of the collective is community engagement on environmental issues through art and ecology. To this end, the collective includes a broad spectrum of talented individuals who bring together a variety of skills and expertise including communication design, beekeeping, creative writing, project management, illustration, carpology, visual arts, community engagement, garden design, industrial design, strategic planning and ecology.
} 


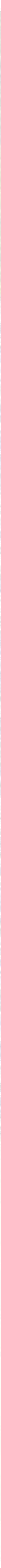

Figure I. Fledglings Composite installation view, Emily Carr University of Art + Design. Ceramic multiples (2018). (Source: chART Projects, credit: Geoff Campbell)

12 | The Journal of Public Space, 5(4), 2020 | ISSN 2206-9658

City Space Architecture / UN-Habitat 
The first-year mortality rate of crows in the Pacific Northwest is $50 \%$ (Link, 2005) and we were prepared for the possibility that over the course of our project, the percentage of our clay fledgling to reach completion might mirror that of the crows we were trying to represent.

Our crows all began their journey as 3.5 ounces of Sierra Red clay; cut from 25-pound blocks and weighed by one of our team before handing the lump over to a waiting member of the public. This 'hand-over' launched the production line process (figure 2) that allowed us to create so many birds in such a relatively short period of time. From that first touch of cutting and weighing the clay to the fired and finished figurine taking flight with its new owner, each bird was handled at least ten times - ten opportunities to be squeezed too hard coming out of the press mold, to crack while drying in the storage boxes, to chip while being glazed or stacked in the kiln, to explode in the firing process, to break while being unloaded and packed and transported and handed back to the public. In the end, we lost twelve -- a surprisingly small number. That is not to say that each fledgling came out of the process perfectly. The hands of a four-year-old will create different oddities as the clay is pulled from the mold and the rough edges smoothed off the form, then the hands of a forty-year-old. We had few rules in the production process. Try and keep the shape of the bird intact (there were four poses to choose from), don't add eyes, leave the newly pressed fledgling with the artist team member at the end of the line for 'banding'. At the end of the line, each bird was numbered by pressing a counter stamp across the underside of its tail. This served to keep track of the number of figures created, mimicked the practice of banding birds in the wild for research and monitoring purposes, and served as the artist signature.

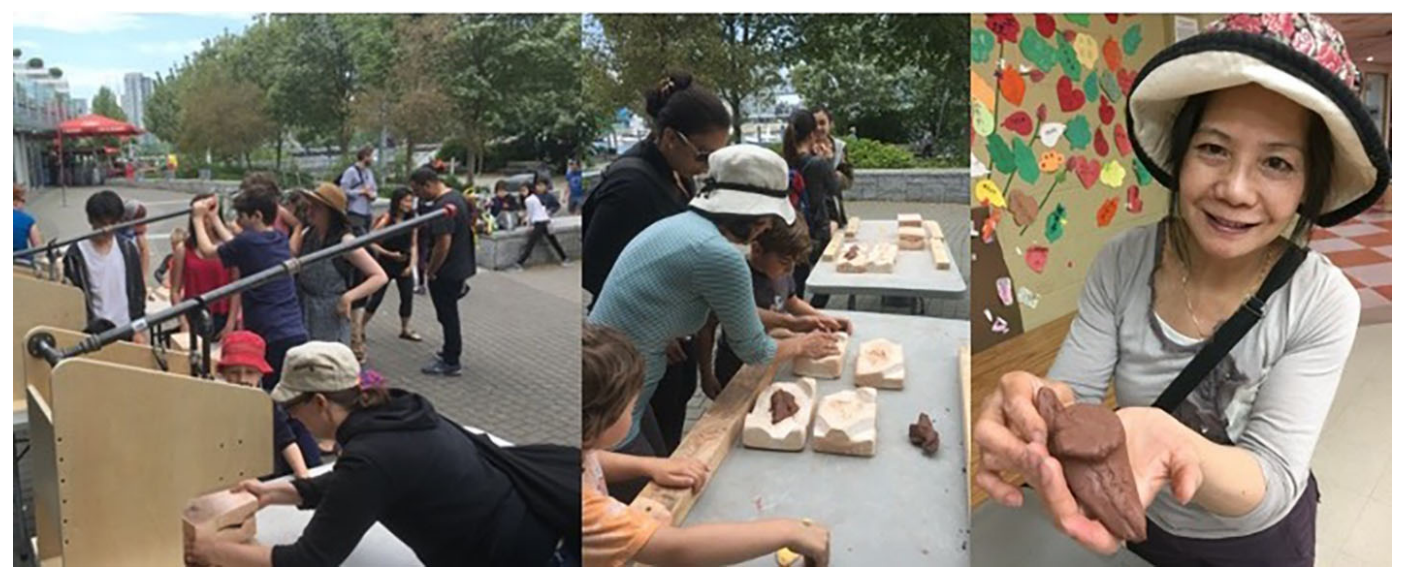

Figure 2. Fledglings workshop detail view, Creekside and Strathcona Community Centres. Ceramic multiples (2018). (Source: chART Projects, credit: Nick Strauss)

Regardless of the age of our participants, no one seemed to be disappointed that they could not immediately take away the bird they helped create. We used a simple phrase in explaining the process. "You are making a gift for someone you never met, and they are making one for you." Many of our participants took selfies with the raw fledgling after it was numbered, holding up \#7 3 or \#4493, knowing that the likelihood of finding that bird again during distribution was near to impossible. They would then hand the bird back to be tucked into the drying boxes for transportation back to the university. 
After the birds were in the drying boxes, the rest of the production was in the hands of our team. Each bird may have only weighed a few ounces, but moving hundreds of them in wooden boxes, packing and unpacking and repacking as they proceeded through the process of drying, glazing, re-drying, loading into the kilns, unloading from the kilns, moving into 5-gallon buckets for easier distribution, and loading them in and out of cars - it is all heavy work.

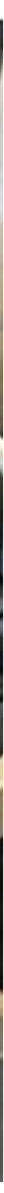

Figure 3. Fledglings progress view, Emily Carr University of Art + Design. Ceramic multiples (2018).

(Source: chART Projects, credit: Cameron Cartiere)

But I found that the sense of community was ever present through this process. As the one team member who participated at every stage of the process, I literally touched every bird. I numbered over 5,500 of them (the collective agreeing that it was better if one person kept tract of the counter), glazed 3,000 of them, and moved (and re-moved) more birds then I care to remember (figure 3). Along the way, certain birds would continually catch my eye and I would remember the person who helped to make it the particularly 'funky' misshaped fledgling made at Creekside Community Centre by a very enthusiastic kindergarten-aged boy, so proud he completed the process by himself (\#|45I). The milestone birds such at \#500 made by a Foundation year student from Nova Scotia at our first workshop at Emily Carr, \#3000 made by a mother who homeschools her two children and returned to several workshops as an opportunity to combine art and science lessons, our final bird \#6000, co-created by myself and a young 
visitor to our university from the USA (figure 4). When those birds passed through my hands again, those makers were present with me in the studio. It was the final handingover, however, that has stayed with me the longest.

Once the fledglings were complete, they returned to the community in two ways.

During the week of the Ornithological Congress, half of the flock were installed in the lobbies of the community centres that hosted our workshops. One would arrive for a swim, to visit the library, or to attend hockey practice only to discover that 800 ceramic fledglings had 'landed' in the entrance lobby. You could simply select a bird and take it home. There were didactic signs about the project, but surprisingly, many centres felt the need to put up an additional sign to let the public know that yes, it was alright to take a bird. Many people would want to leave a contribution at the reception desk. Instead, we left instruction to encourage those people to actually take two birds and give one to someone else and share about the project and the information they learned about urban crows. Because that was the main goal of the project.

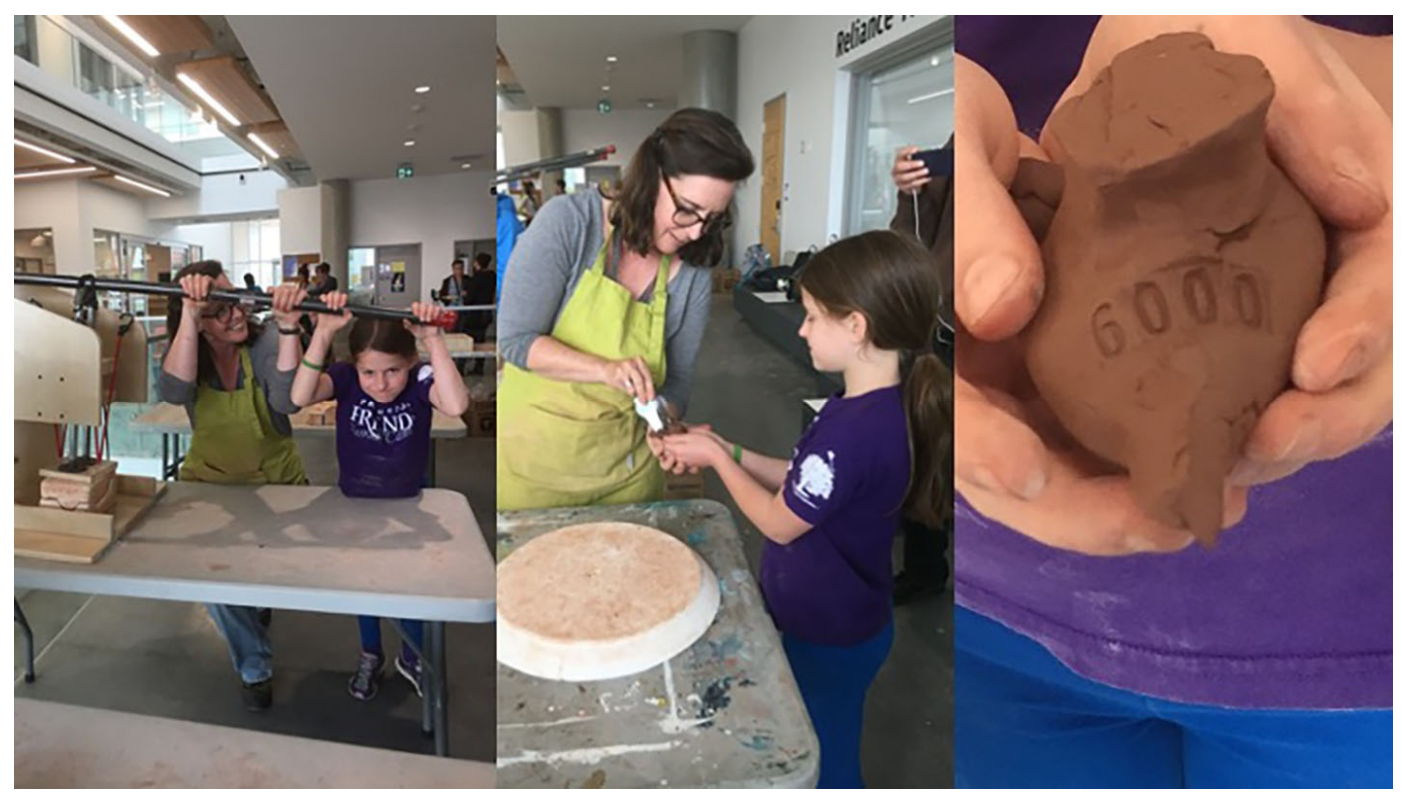

Figure 5. Fledglings making the last bird, Emily Carr University of Art + Design. Ceramic multiples (2018). (Source: chART Projects, credit: Nick Strauss)

Each fledgling was more than an art object. Each bird was also the conveyer of information. An opportunity to have a discussion (if even briefly) about the decline in bird species, how adaptive crows are, the mortality rate of fledglings, our shared environment. It was also an opportunity to hear peoples 'crow stories' - why they loved crows, or hate crows (there seemed to be few people neutral on the subject). These were moments when we could discuss why they might have been 'dive-bombed', what to do to avoid those situations in future, how to tell a crow from a raven, and the important role of crows as scavengers in nature (Link, 2005). We had these discussions during the making of the fledglings, but we also had these discussions with people when we were installing the birds back into the community centres, and when we distributed the birds at our other events in the project. 


\section{Weaving Through Public Space}

Our second artwork in As the Crow Flies was Nesting Nests - a large scale temporary sculpture made by creating hand woven nests for the broad array of birds that are native to Metro Vancouver, from the Anna's Hummingbird to the Bald Eagle. The nests were assembled together on a birch armature to create one large nest $(4.5$ meters in diameter) representing the range of habitats needed for birds to survive in our region. The sculpture was designed by myself, artist Jaymie Johnson, and industrial designer Christian Blyt. Nesting Nests expanded on Johnson's previous BFB work, Bumble Baskets. ${ }^{7}$ A series of workshops were scheduled from March 2018 through July 2018 at community centres, parks, and other local sites for the public to weave the nests using coil basket techniques. These workshops were a unique opportunity not only for creative production, but also to continue our practice of engagement in environmental education, story-telling and community building. The materials for the nest building was harvested by our team in collaboration with the Vancouver Parks Department, through their invasive species abatement program. We harvested dozens of bags of English ivy, Scotch broom, and Periwinkle and prepared it for transformation into art materials. The weaving of each basket became an opportunity to talk about the 19 invasive plant species identified in Metro Vancouver, what this means for our common spaces like parks and berms, how and when ground nesting birds might be taking up residence in blackberry bushes, and why English ivy is probably not your best choice for ground cover. $^{8}$

The giant nest was assembled to coincide with the opening of the Ornithological Congress and was installed on the recently acquired Arbutus Greenway. ${ }^{9}$ This pedestrian and bikeway corridor runs nine kilometres from the southern edge of the city, along the Fraser River in the neighbourhood of Marpole, northward to False Creek and Granville Island. This former Canadian Pacific Railway (CP Rail) line had been undergoing a considered transformation since 2016. The changes were occurring in stages, with testing different types of paving materials, active and ongoing community consultations (including a series of 'design jams'), and temporary interventions such as seating, a little free library, and a pop-up pollinator garden. Nesting Nests became a part of that testing process. Prior to our 3-week installation, there had been no public art officially produced along the greenway. There were a couple of guerrilla activities including the person who painstakingly painted all seventeen electrical boxes along the greenway to resemble signalling flags. ${ }^{10}$ Through their own expense, they continue to maintain this series of mini-murals and the City unofficially accepts this contribution to the public realm by not painting over the boxes. But this type of unsanctioned art action did raise questions within the various departments who engaged in the commissioning

\footnotetext{
${ }^{7}$ For more information on the Bumble Baskets project see http://borderfreebees.com/terra-novapollinator-meadow/

${ }^{8}$ For more information on invasive plant species in Metro Vancouver see

http://www.metrovancouver.org/services/regional-planning/conserving-connecting/invasivespecies/Pages/default.aspx

${ }^{9}$ For more information on the history, development, and planning of the Arbutus Greenway see https://vancouver.ca/streets-transportation/arbutus-greenway.aspx

${ }^{10}$ https://www.vancouverisawesome.com/events-and-entertainment/vancouver-resident-arbutus-corridorboxes-1944042
} 
of public art across Vancouver. These various departments include the Public Art Department, the Graffiti Management Unit, the Parks Department, the Engineering Department, the Sustainability Unit, and the Library. Not surprisingly, these various departments are not always in communication with each other in terms of commissioning policies or following a comprehensive public art plan. Prior to our engagement with the Arbutus Greenway Design Unit, it wasn't apparent that the greenway fell outside of the City's Park Department, nor was it connected with the Engineering Department. The Arbutus Greenway project was forging new ground for interdepartmental collaboration as well as experiencing some cross-department confusion and miscommunication. At various stages along the way, our sculpture was approved, rejected, re-approved, re-rejected, and finally successfully installed. This experience helped lay the foundation for a public art policy for the Arbutus Greenway which has gone on to commission several murals and other temporary artworks. Public art has a long history of serving as a lightning rod for other issues, and our project certainly highlighted the need for an official commissioning process for the greenway, but the only complaints the department received about the sculpture was when it was gone. People up and down the corridor asked, where their nest went. The answer was, Port Moody.

From the beginning we knew that Nesting Nests had only a temporary home on the Arbutus Greenway and we wanted to ensure that the life-span of the work would be proportional to the collective effort of creating the sculpture. One of my previous municipal partners, who had worked with me on BFB, had moved over to lead the Parks Department at Port Moody. She contacted me to see if chART was doing anything for the Ornithological Congress. I discussed the various works within As the Crow Flies and our desire to have Nesting Nest settle into a more extended situation. While the sculpture was design to eventually biodegrade, the work had at least a threeyear window before it would need to be recycled. Three years during which the work could be a focal point of artivism. She was very enthusiastic about the design and asked if we would consider pitching the idea, to other department heads in the municipality, of moving the sculpture down the road to Port Moody after the installation in Vancouver was over. Having decades of experience working with public art, I know the hazards of simply moving a sculpture conceived for one site on to another. If the work is placespecific, connecting not only to the topography of a location, but also the people and histories of that location; how do you inspire those same connections for the community in the next site? The solution was found in the making - the community engagement involved in making the individual nests that helped to create the overall sculpture. So, while we held workshops in Vancouver to weave nests from invasive plants harvested in that city, we also held similar workshops in Port Moody with materials harvested by Port Moody's Parks Department (figure 6).

In addition to weaving nests, discussing invasive plant species, birds in the region and shared habitat, we also talked to people about the artwork that would be coming to their city. We explained how they, too were contributing to the creation of this work and that the nests they were making would be added to the sculpture once it was sited in Port Moody. In essence the sculpture would not be fully complete until it was installed in their park. This community connection helped to transition the work successfully into its second location. The work was not viewed as a 'hand-me-down' from the big city of Vancouver. Rather, people in our Port Moody workshops joked 
how Nesting Nests was going to be having previews in Vancouver or how it was on loan. Our Port Moody participants were also keen on designing nests for birds that were specific to their region (the Purple Martin in particular, a red-listed species in $\mathrm{BC}^{\prime \prime}$ ).

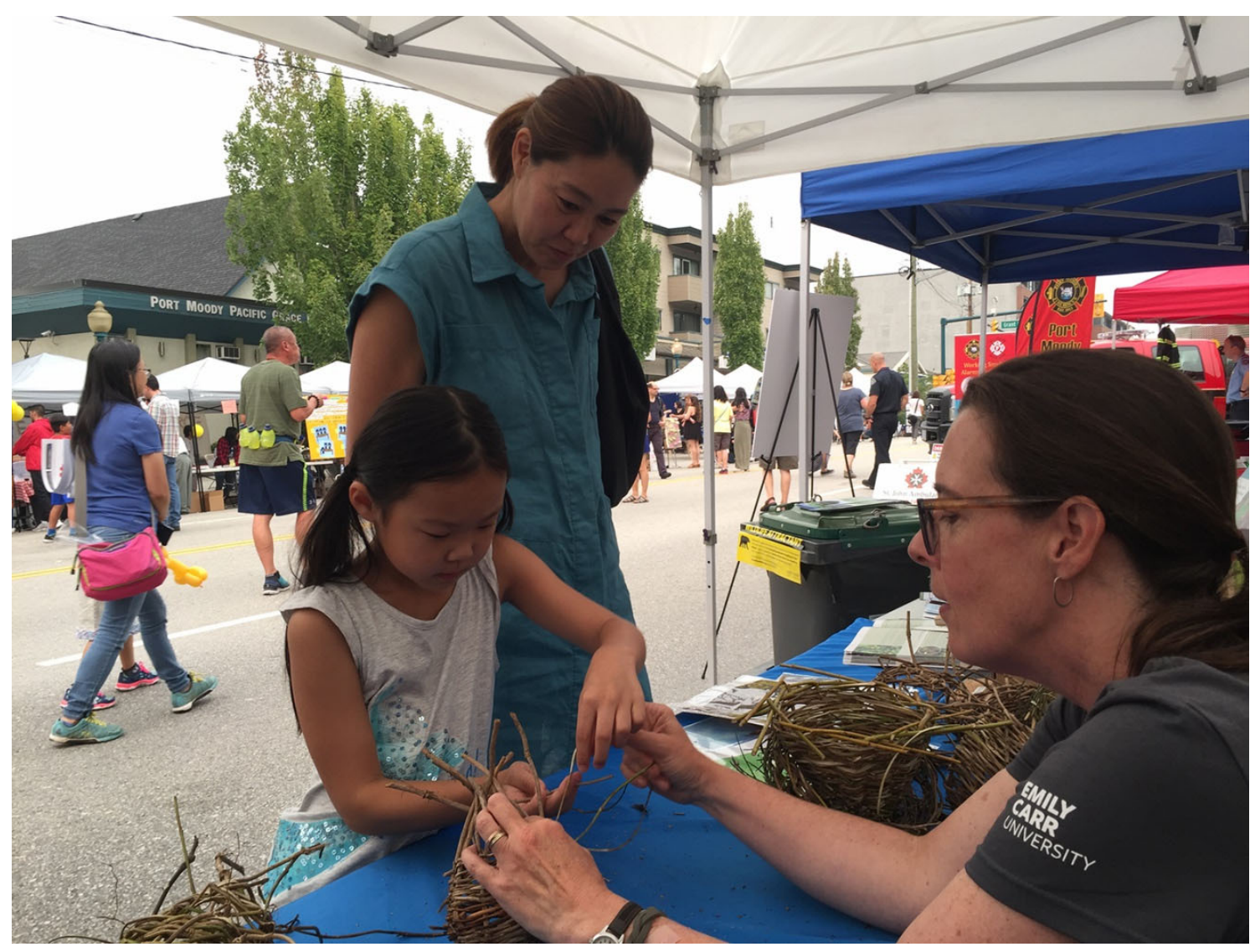

Figure 6. Nesting Nests workshop, Car-free Day, Port Moody, BC (2018).

(Source: chART Projects, credit: Nick Strauss)

On the Vancouver end, regular users of the greenway were writing into the city to express their pleasure with the public sculpture, how it was the type of work they had been hoping to see on the corridor - work that was responsive to the environment. From my observation, it was not without a hint of glee that the officials at Port Moody denied the request from Vancouver to keep the sculpture sited on the Arbutus Greenway for an additional six weeks. The people of Port Moody had waited long enough for their sculpture and they wanted to welcome it home.

\footnotetext{
"For more information on red-listed birds and Purple Martin recovery efforts in British Columbia see https://www.georgiabasin.ca/PUMA\%20publications/Cousens_et_al_PUMA\%20recovery\%20in\%20BC\%20S ARC\%2704.pdf
} 


\section{Animating an Environmental Action}

The third and final component of As the Crow Files was the collaborative animation project On the Wing. Following that conceptual-line we charted across the city, On the Wing consisted of three events featuring outdoor projections and live music. The animation was created by Associate Professor Martin Rose and four students from Emily Carr University. Continuing the theme of the crows' nightly migration across Vancouver's skies, the animation was designed in three parts. During the week of the congress, Lift Off took place at MacLean Park on Monday, August 20 (the northern point on the line); Flight occurred on Wednesday, August 22 at the Dancing Waters Fountain Plaza at Queen Elizabeth Park (midway on the line); and finally Landing was held Friday, August 24 on the Arbutus Greenway at 57th Avenue where Nesting Nest had been installed.

We also commissioned artist and musician David Gowman (known locally as Mr. FireMan) and his band, The Legion of Flying Monkeys Horn Orchestra, to produce a musical composition. The band played the piece live, utilizing both conventional and handcrafted instruments, including long wooden horns fashioned from empress trees and royal paulownia. Gowman's studio was in the field house at MacLean Park where the first event occurred and he was well versed in the activities of the crows who regularly visited the park. The daily observations influenced the tone and pace of the musical score.

Often when one views animation it is connected to a device such as a smart phone, laptop, or tablet. Or it is projected in a darkened movie theatre with people in fitted seats in stationed rows. In short, it is a passive activity. But what happens when animation is moved outdoors, into public spaces and the chairs disappear and we lift our heads away from the screen? Can animation help animate public space? Certainly, there is a history of outdoor projections from the (nearly) by-gone era of the drive-in movie to the works of public artists like Krzysztof Wodiczko who since the 1980s, has been projecting videos onto historical statuary and monuments, transforming them into new platforms for the powerless in society. Through his projections, veterans of countless wars, Hiroshima survivors, mothers grieving their murdered children, and abused laborers have professed their personal stories from these public pedestals. With the use of Projection Mapping ${ }^{\prime 2}$, a rapidly developing digital technology and art form that turns any three-dimensional object into an innovative canvas, public space has the potential to become a new kind of public theatre. However, not all artists have access to high tech equipment and large-scale productions. We wanted to bring a relatively low-tech solution to animating public space with high-level community engagement. For this we utilized five easily attainable components - a data projector, a portable battery, a laptop, a hand-crafted portable screen, and a tricycle (figure 7). Our mobile projection unit allowed us to illuminate the range of terrains that made up the three locations for our project.

The live music and adaptive score were also key elements for animating these public spaces. Gowen and his orchestra composed their performance to accompany the animation, but they also provided improvisational moments that responded to the

\footnotetext{
${ }^{12}$ For more information on projection mapping, also known as video mapping see http://projection-mapping.org
} 
activities of the audience. If children were dancing along with the hopping crows on the screen or lifting their arms to imitate the flapping wings of the birds in flight, the musicians responded. So, each performance proved to be a unique experience and our audience grew as the week progressed and by the final event, we had to provide traffic control to accommodate all the pedestrian and bike traffic that culminated at our site on the Arbutus Greenway (figure 8).

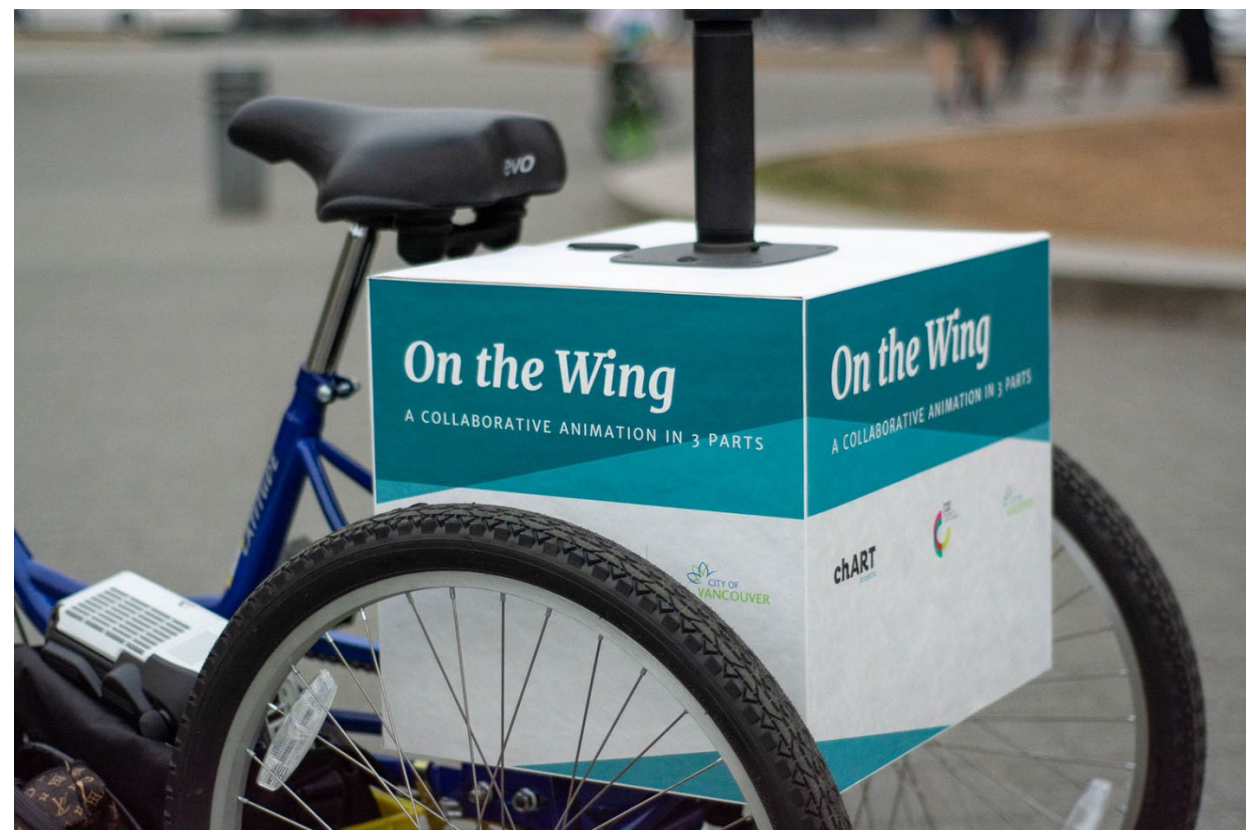

Figure 7. On the Wing, Mobile animation tricycle, Vancouver. (2018).

(Source: chART Projects, credit: Geoff Campbell)

\section{Realizations from As the Crow Flies}

I mentioned previously that there were two ways that the public could 'official' attain one of our fledglings. The first, by selecting one from the hundreds of clay birds distributed to the community centres that hosted one of our workshops. The other way was by attending one of the animation events and having a member of the chART team present a fledgling to you.

But we weren't just handing out birds randomly to the crowd. With each handover, we would read off the number banded on the bird. "This is number 3,210 of 6,000" and place the fledgling into the palm of the hand of the recipient. This gesture created the moment for an active conversation (figure 9). A conversation about the project, about ecology and conservation, about the power of art to move people into different ways of seeing the world around them. It was amazing to see how people responded to receiving a bird - specifically designed to nestle comfortably into the hand; to have just enough weight to feel substantial, but also delicate enough to convey vulnerability. 


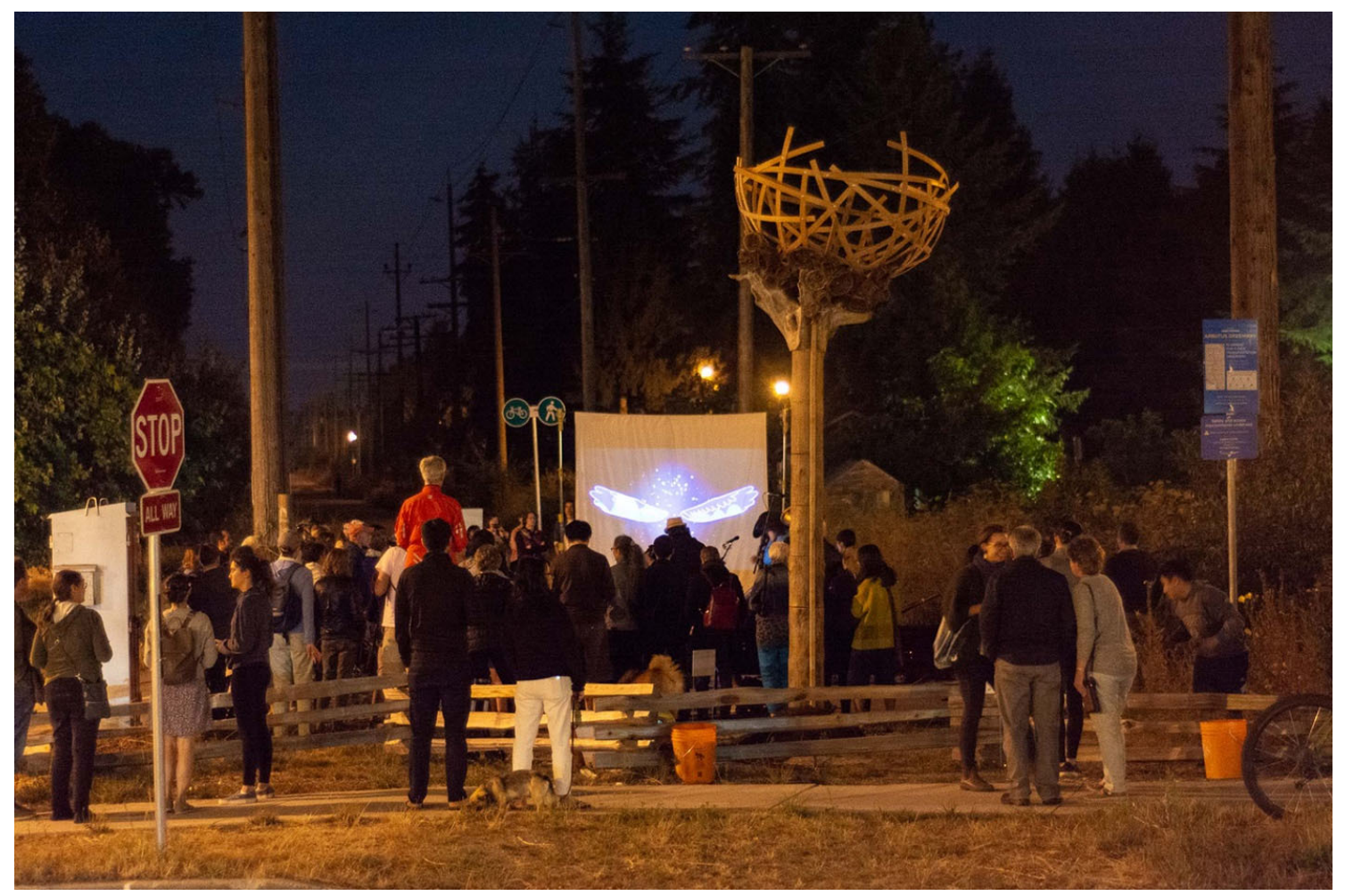

Figure 8. As the Crow Flies, three public artworks (Nesting Nests, On the Wing, Fledglings) come together on the Arbutus Greenway, Vancouver. (2018). (Source: chART Projects, credit: Geoff Campbell)

I teach an advanced seminar on social practice art and last year I tried a small experiment as a way of testing how subtle an artivism gesture might be and still move an individual towards a new awareness. I had thirty fledglings left from the project. I was schedule to present As the Crow Flies in the second half of the class. During the break, I ushered everyone out of the room and instructed them not to come back until I opened the door for them. I proceeded to place a crow at every other seat. At the end of the break, I opened the door and let everyone back in. Those who had a bird in front of them immediately picked up the fledgling to claim it. Those that didn't have a bird glanced around to see it they had missed it, followed by a look somewhere between confusion and disappointment. I presented on the project and at the end, I went to each student who had not been left a bird and presented a fledgling directly to them. "This is number 329 of 6,000 . This is number 2,499 out of 6,000." Fifteen times I repeated this action. Everyone held a bird. I then asked how that felt - to find a bird versus to receive a bird? They talked about the delight of having a bird at their seat (aren't I the lucky one) and the disappointment (why didn't I get one) followed by the amazement of being presented with a bird and the subsequent disappointment by others who didn't experience that direct exchange. In this case the artivism was the action of directly receiving the artwork from one hand to another. That gesture made the connection to the artwork more personal and by extension, the connection to the environmental issue became more personal as well. 


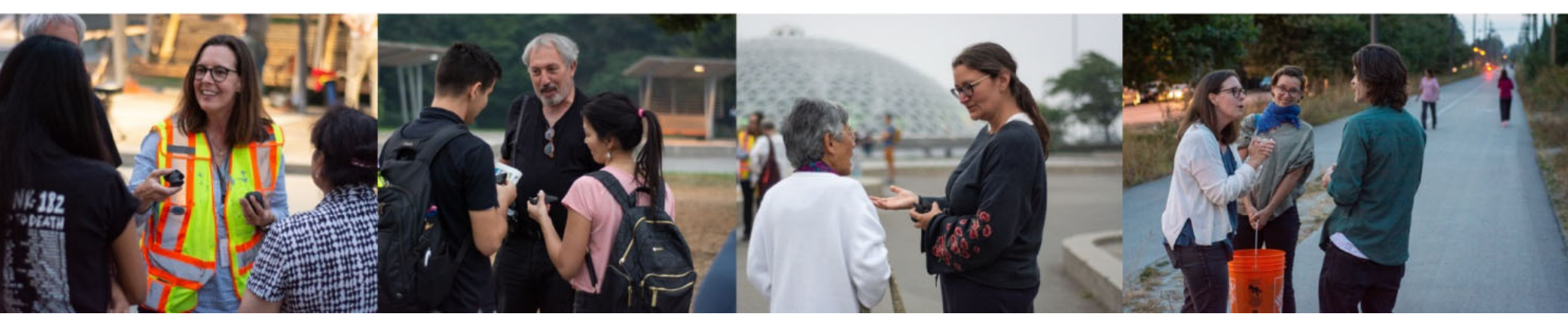

Figure 9. Fledglings Composite view of community engagement at multiple sites in Vancouver. Ceramic multiples (20I8). (Source: chART Projects, credit: Geoff Campbell)

As the Crow Flies was undoubtedly an ambitious vision, but as we developed the project along with our city, civic and creative partners, the potential for community engagement proved to be substantial. The virtual ten kilometre "art-line" between our sited sculpture and the interventions and public performances revealed an incredible opportunity to connect community and creativity with the plight of birds at key locations across Vancouver. The concept of this symbolic line encouraged the public to experience the diversity and beauty of the native birds of our city at multiple sites, both physically and emotionally. It is important to note that the three, interactive communityengaged art projects (Nesting Nests, Fledglings, and On the Wing) were driven by hours of creative production. These were labour intense projects and as such, the essential component was artist engagement. As environmentally driven art projects, the cost of materials was relatively low compared to the time and creative energy it took to transform those materials into inspiring and substantial artworks.

While our project certainly took advantage of the amazing assembly of scientists, conservationists, and advocates who 'landed' in Vancouver during the International Ornithological Congress, the main goal of As the Crow Flies was to have a lasting effect on the general public's relationship to birds, beyond the attention focused on Bird Week and the arrival of the Congress. Two years on and I still receive notes from people who received one of our fledglings. It might be a photo of one of our little ceramic birds taken of on the subway in Helsinki or a fast train to Tokyo. It might be a request from a school teacher to explain how to safely harvest English ivy so they can use it in their classrooms as part of an upcoming ecology lesson on bird habitat. Or interest from Mexico to present the animation during a COVID- 19 online arts festival. When I walk to the grocery store each week, I pass a garden fence where three black fledglings sit atop the railing. I don't know who lives there but over the past two years I have noticed more bird feeders and more native plantings in the garden. The fledglings sit on the fence year-round, through rain and snow and sun. One has a chip missing from its tail, but otherwise they look the same as the day they came out of the kiln. You could easily pluck one off the top of the fence, but no one has taken them. I have seen passers-by taking notice, pointing the little birds out to a companion as they walk together up the hill. I wonder about their conversation. Are they a bit more aware of the bird calls around them? Do they look for that ground nest before cutting away at the bramble of blackberry bush that is taking over the back-garden fence? Will they be reminded to buy an extra bag of sugar to replenish the hummingbird feeder in the middle of January now that the Anna's hummingbird is a year-round resident? 
Activism can take many forms - marching in the streets, letters to government, online petitions, sit-ins, and boycotts. Art-and-activism is art-in-action. We certainly take notice of the grand gestures; towering murals, projections across museum facades, yarn-bombing an entire bridge - these are works that demand attention. But does that attention last when the work is no longer in view? Activism can also take more subtle forms - daily changes in behaviour and consumption, mindfulness and acceptance of differences, kindness as an act of resistance. Admittedly, 6,000 ceramic birds laid out all at once is a dramatic sight and we certainly went to the effort to stage that moment before we began the week-long process of sending those fledglings out into the world. But I think the real power of that piece was the "bird in the hand". The individual connection to the making, the giving, and the receiving of that little bird. A daily reminder to consider one's actions in a world that we share with so many others. An opportunity to shift the gaze from an anthropocentric view to a more ecocentric perspective. This is a social practice and public art methodology that could be applied to many environmental issues around the world. Regardless if one is addressing specific issues such as air pollution, plastics in the oceans, endanger species, or broader issues such climate change and global food security, the key is to start with the individual connection to the problem at hand. There are multiple approaches to environmental action and with As the Crow Flies, our way forward as an action to address our collective environmental crisis proved to be bird-by-bird.

\section{Acknowledgement}

As the Crow Flies was produced with financial and in-kind support from Emily Carr University of Art + Design, the City of Vancouver Public Art Community Grants, the Arbutus Greenway Design Department, the Vancouver Bird Festival, and the City of Port Moody. As the Crow Flies

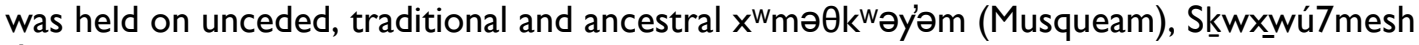
Úxwumixw (Squamish), and səlilwəta?ł (Tsleil-Waututh) territories.

\section{References}

Anielski, M. (2019) Research Related to Boreal Caribou Habitat Restoration Economics in British Columbia: a Report Prepared for the David Suzuki Foundation. David Suzuki Foundation. Retrieved at: https://davidsuzuki.org/wp-content/uploads/2019/04/researchrelated-to-boreal-caribou-habitat-restoration-economics-british-columbia.pdf

Carson, R. (1962) Silent Spring. Houghton Mifflin. Boston, MA, USA.

Cartiere, C. and Holmes, N. (2019). Design on the Wing: Collaborative Work with Nature. In Design and Nature (pp. 160-166). Routledge.

Goris, Y. and Hollander, S. (2017) Activism, artivism and beyond. Inspiring initiatives of civic power. Versión digital]. Retrieved at: https://www.partos.nl/fileadmin/files/Documents/Activism_Artivism_and_Beyond.pdf

Haupt, L.L. (2009) Crow planet: Essential wisdom from the urban wilderness. Little, Brown Spark.

Lacy, S. (1995) Debated territory: Toward a critical language for public art. Mapping the terrain: New genre public art, Pp. I7I-I85.

Link, R. (2005) Living with wildlife-Crows. Washington, DC: Department of Fish \& Wildlife. Retrieved at: https://wdfw.wa.gov/sites/default/files/publications/006II/wdfw006II.pdf 
Marzluff, J.M. and Angell, T. (2013) Gifts of the crow: how perception, emotion, and thought allow smart birds to behave like humans. Simon and Schuster.

Marzluff, J.M. and Angell, T. (2007) In the company of crows and ravens. Yale University Press. Rosenberg, K.V., Kennedy, J.A., Dettmers, R., Ford, R.P., Reynolds, D., Alexander, J.D., Beardmore, C.J., Blancher, P.J., Bogart, R.E., Butcher, G.S. and Camfield, A.F. (20I6) Partners in Flight landbird conservation plan: (2016), Revision for Canada and continental United States. Partners in Flight Science Committee, 35. Retrieved at: https://partnersinflight.org/resources/the-plan/

Savage, C. (2015) Crows: Encounters with the wise guys of the avian world. Greystone Books Ltd.

Wilsey, C., Bateman, B., Taylor, L., Wu, J.X., LeBaron, G., Shepherd, R., Koseff, C., Friedman, S. and Stone, R., (2019) Survival by Degrees: 389 Bird Species on the Brink. National Audubon Society: New York, NY, USA. Retrieved at: https://www.audubon.org/sites/default/files/climatereport-2019-english-lowres.pdf 